\title{
Csinta
}

\section{Implementation of Extreme Programming Method in Web Based Digital Report Value Information System Besign}

\author{
Adi Supriyatna*, Diah Puspitasari \\ Bina Sarana Informatika University \\ Jl. Kramat Raya No.98 Senen, Jakarta Pusat 10450. \\ *Corresponding author: adi.asp@bsi.ac.id
}

\begin{abstract}
The process of data collection and processing of student scores that is carried out continuously from year to year is felt to be unable to produce fast, precise and accurate information, because it takes a long time. Computerized information system processing student grades is expected to be able to ease the work of homeroom teachers, so that they can produce valid information in a short time and can be accessed anywhere. With good processing and management, value data processing will be easier, faster, more accurate. The purpose of this research is to build a web-based digital report card information system as a solution offered to help solve problems faced by schools. The system development method used is Extreme Programming (XP) which has several stages, namely planning, designing, coding, testing and Software Increment. The results of this study are the creation of an information system that can provide several advantages as well as efficiency and effectiveness in processing information and managing value data up to the printing of student report cards.
\end{abstract}

Keywords: Digital Report, Extreme Programming, Information System Design.

\section{Introduction}

Education plays an important role in supporting the development of the Indonesian state[1]. Value is one measure of the success of students taking education in school[2][3]. The process of data collection and processing of student scores that is carried out continuously from year to year is felt to be unable to produce fast, precise and accurate information, because it takes a long time. Computerized information system processing student grades is expected to be able to ease the work of homeroom teachers, so that they can produce valid information in a short time and can be accessed anywhere. With good processing and management, value data processing will be easier, faster, more accurate[3]. An information system for processing student grade data using computer media that will make it easier to record student grade data so that it becomes an effective medium for the development of education[4].

Report card is a report on the results of student learning activities during a certain period which is implemented in the form of the value of a group of subjects accompanied by an assessment of personality, attitudes and behavior. The period included is the period or level of learning in the form of a semester period[5]. With this report card information system, it can provide convenience, minimize errors, and improve data security that is more secure[6]. There is a need for the development of technology that supports the world of education more advanced, one of which is an information system for processing student value data [7]. Using an information system can help present value processing information, which is accurate and relevant and can save time for recording grades in report cards, grade reports, recap of student grades so that it will be easier to provide information and the results of the monthly grade recap report needed will be easy. obtained on time[8]. 


\section{Research Methodology}

2.1. Extreme Programming (XP)

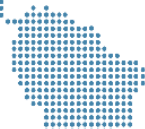

Extreme Programming (XP) is one of the most widely used argitle methods become a very popular approach[9]. Extreme Programming (XP) is a methodology used for software development aimed at improving software quality against changes and user needs[10]. In XP there are several stages in the development of information systems, namely Planning, Design, Coding, Testing and Software Increment

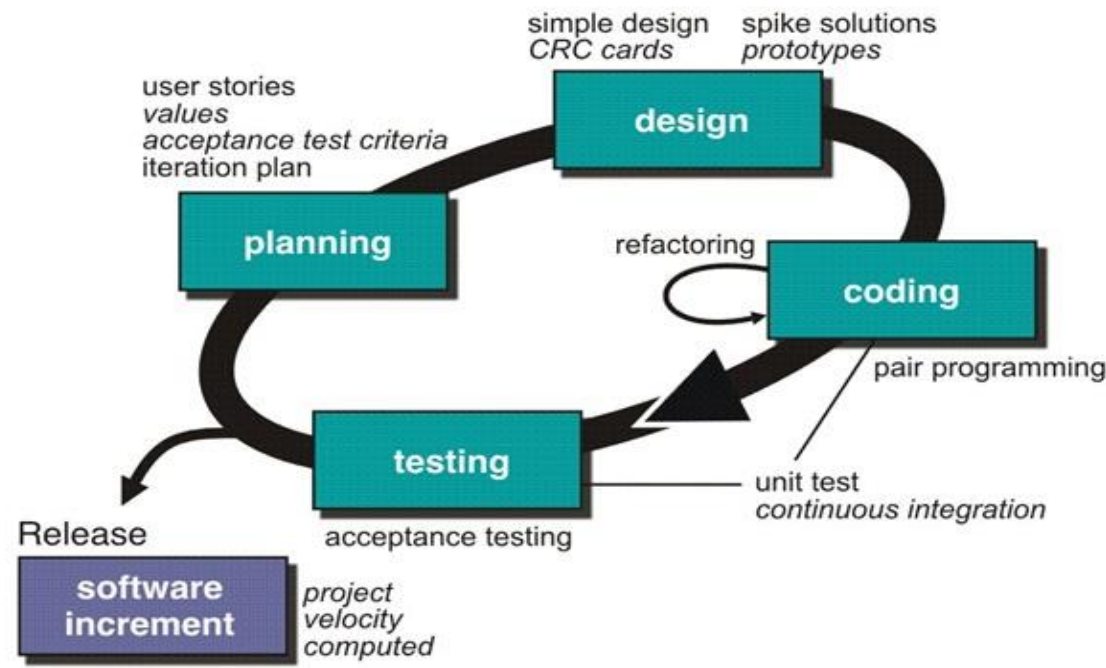

Figure 1. Extreme Programming

The steps involved in designing a web-based digital report card information system are as follows:

a. Planning.

At this stage, it begins by gathering requirements from users to ensure users understand the system's business processes and get a clear picture of the main features, functionality and desired outputs. This stage starts from identifying problems that arise in the current system, then analyzing user needs for the system to be built.

b. Design.

At the design stage, system modeling and data modeling are made. The system modeling used is the Unified Modeling Language (UML) which consists of several diagrams including Use-Case Diagrams, Activity Diagrams, Component Diagrams and Deployment Diagrams. Meanwhile, for database modeling using Entity Relationship Diagram (ERD) based on the results of the needs analysis obtained.

c. Coding.

This stage is the implementation of the system model design that has been made into program code that produces a prototype of the software. PHP programming language combined with HTML, CSS and Javascript. For database implementation, the Database Management System used is MySQL.

d. Testing.

This stage is the stage of testing the application that has been built, at this stage it is determined by the system user and focuses on the features and functionality of the entire system and then reviewed by the system user. The method used in testing is Black-Box Testing by testing the input and output generated by the system. 
e. Software Increment

This stage is the stage of system development that has been nade in stagẹs wixhich is carried out after the system is implemented in the organization by services or content that results in increasing the functionality the system.

\section{Result and Discussion}

\subsection{Planning.}

a. Identification of problems.

The problem faced by several schools is the continuous processing of academic data from year to year starting from the calculation of test scores and assignment scores until the formation of report cards requires fast, precise and accurate information. In addition, student progress reports cannot be controlled in detail by the principal with a conventional system. Therefore, the formulation of the problem that can be identified is how to design a web-based academic information system for processing value data that is able to facilitate the work of homeroom teachers and school principals to control student development online.

b. Analisa Kebutuhan.

This web-based digital report card information system intends to provide facilities for teachers to enter grades to make it more practical and accurate to print report cards digitally. In addition, administrators can manage content online. The following is a requirement specification of this web-based digital report card information system.

1) Teacher
a) Teachers can Login.
b) Teachers can change Personal Data and Password.
c) Teachers can see Student data.
d) Teachers can see student scores.
e) Teachers can input student scores nilai.
f) Teachers can print student grade reports.
g) Teachers can Logout.

2) Administrator
a) Administrator can Login.
b) Administrator can manage Teacher data.
c) Administrator can manage Subject data.
d) Administrator can change Personal Data and Password.
e) Administrators can add, update and delete Student data.
f) Administrator can add, update and delete Value data data.
g) Administrators can print student grade reports.
h) Administrator can Logout.

\subsection{Design.}

Based on the results of the needs analysis that has been determined, then at this stage the system modeling design is carried out using the Unified Modeling Language (UML) diagram and the database modeling design is using the Entity Relationship Diagram (ERD).

a. System Modeling.

1) Use Case Diagram Teacher Page. 


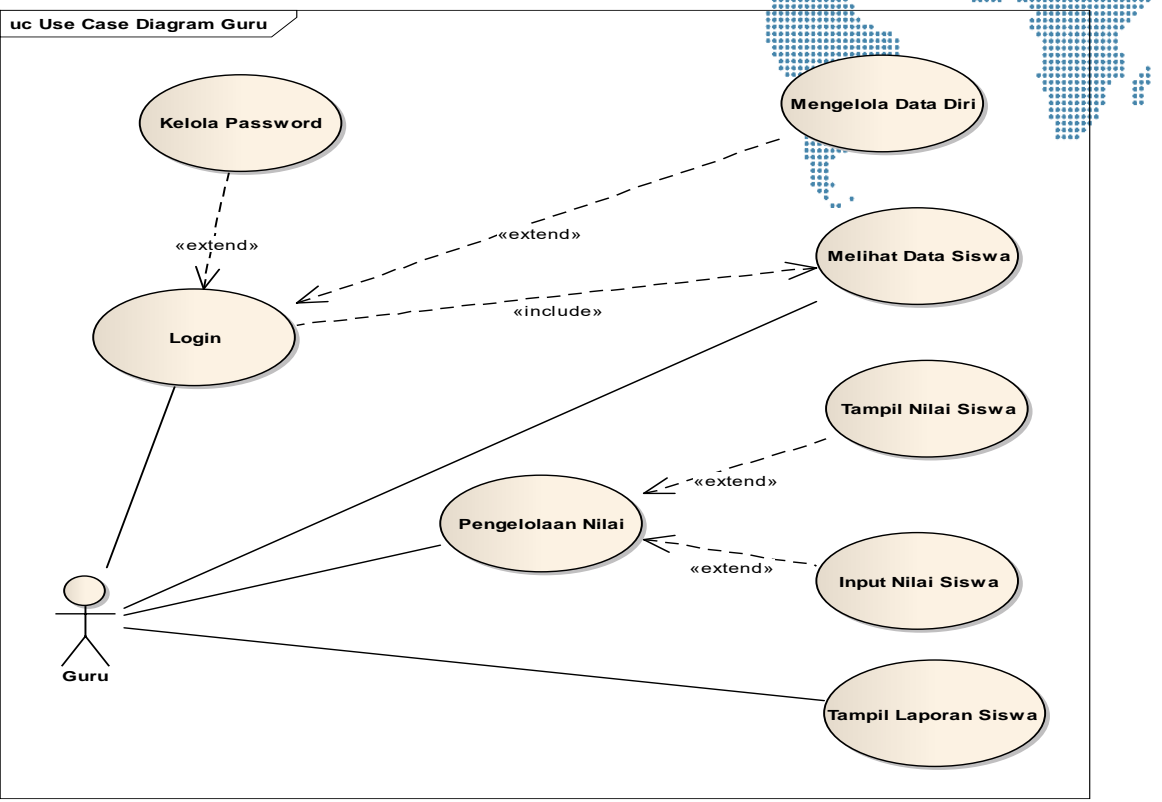

Figure 2. Use Case Diagram Teacher Page

Figure 2. Describes a use case diagram from the teacher's side, where in this information system the teacher can perform several activities, namely logging in, managing personal data, viewing student data, managing value data, and printing student report cards.

2) Use Case Diagram Administrator page.

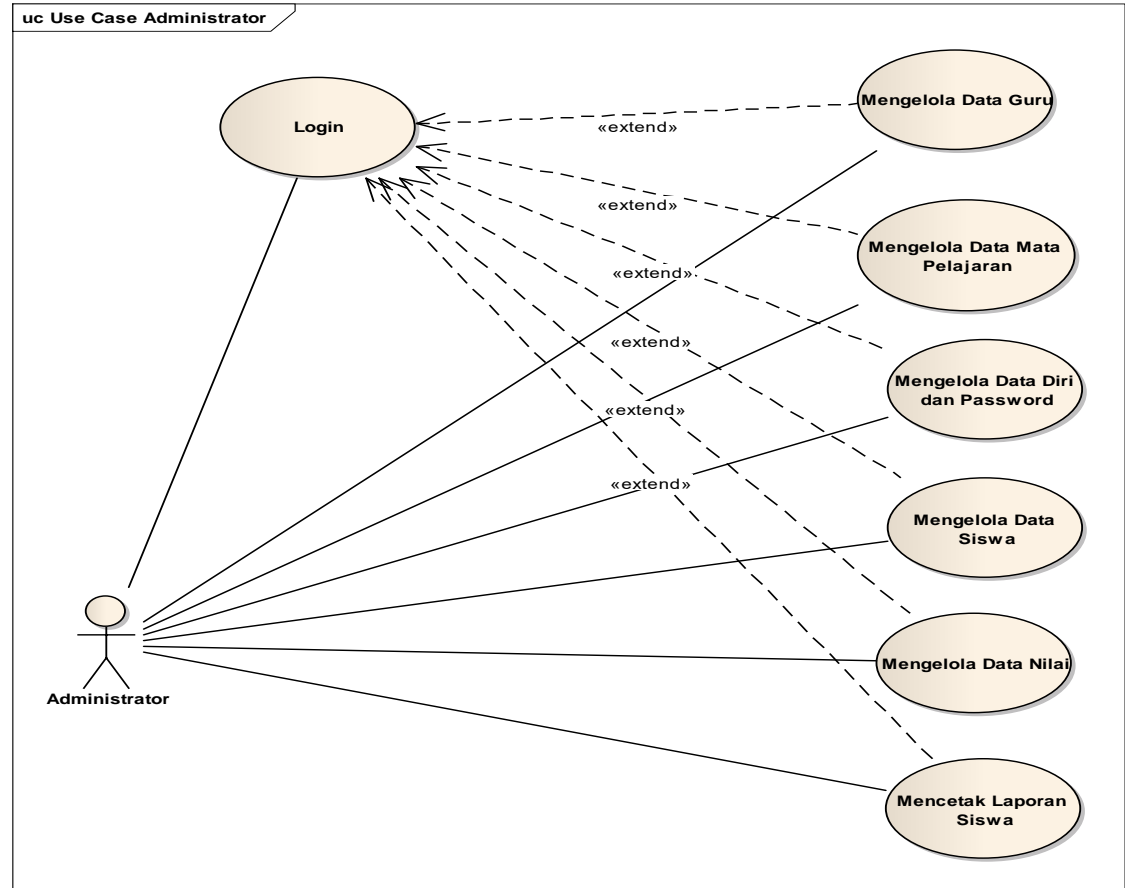

Figure 3. Use Case Diagram Administrator Page

Figure 3. Describes a use case diagram from the administrator's side, where in this information system the teacher can perform several activities, namely logging in, managing teacher data, managing subject data, managing teacher data, managing student data, managing grade data to printing student report cards. 
3) Activity Diagram Sistem Informasi Raport Digital

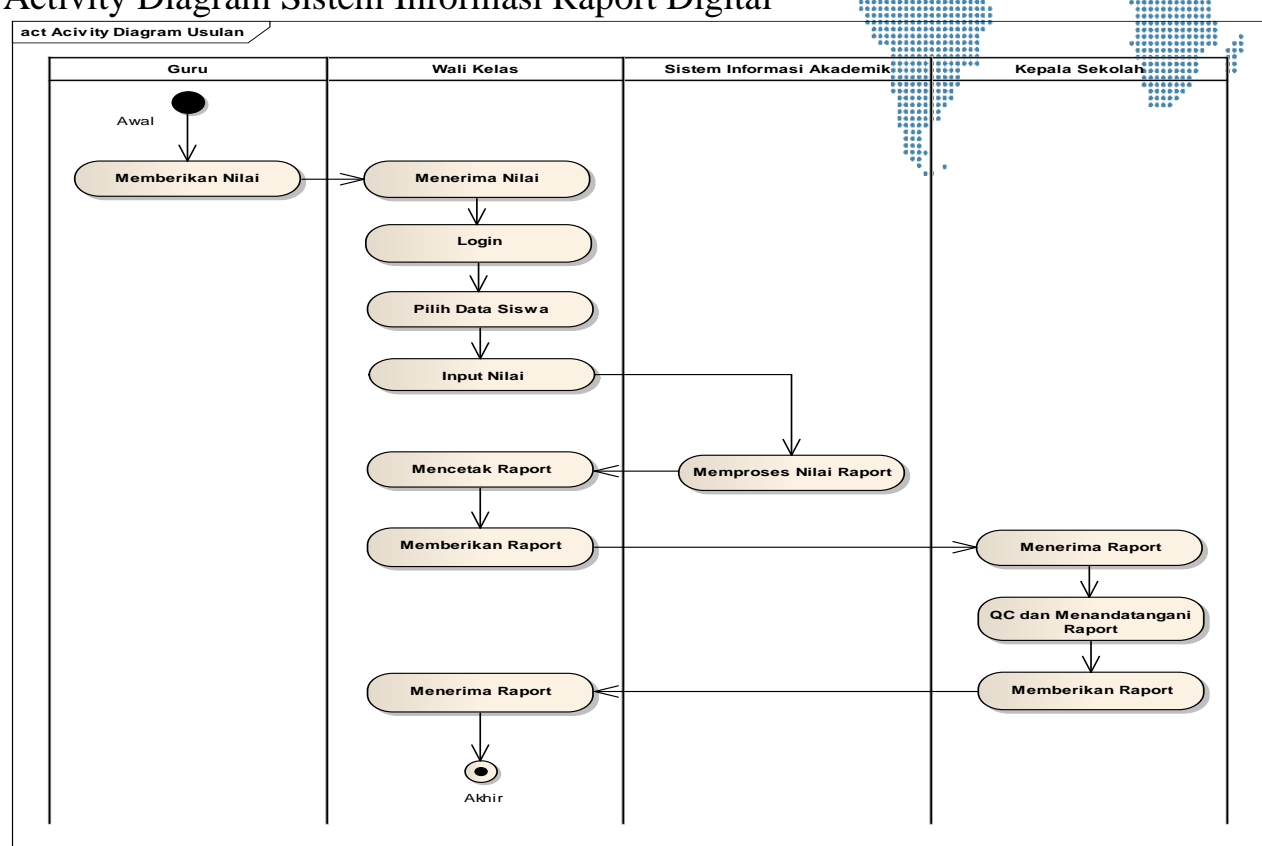

Figure 4. Activity Diagram Sistem Informasi Raport Digital

Figure 4. shows a diagram of the activity or workflow of the digital report card information system, starting with the teacher giving grades that are carried out using a digital report card information system, the quality control and validation process by the principal until the report card is received by the homeroom teacher.

b. Pemodelan Basis Data.

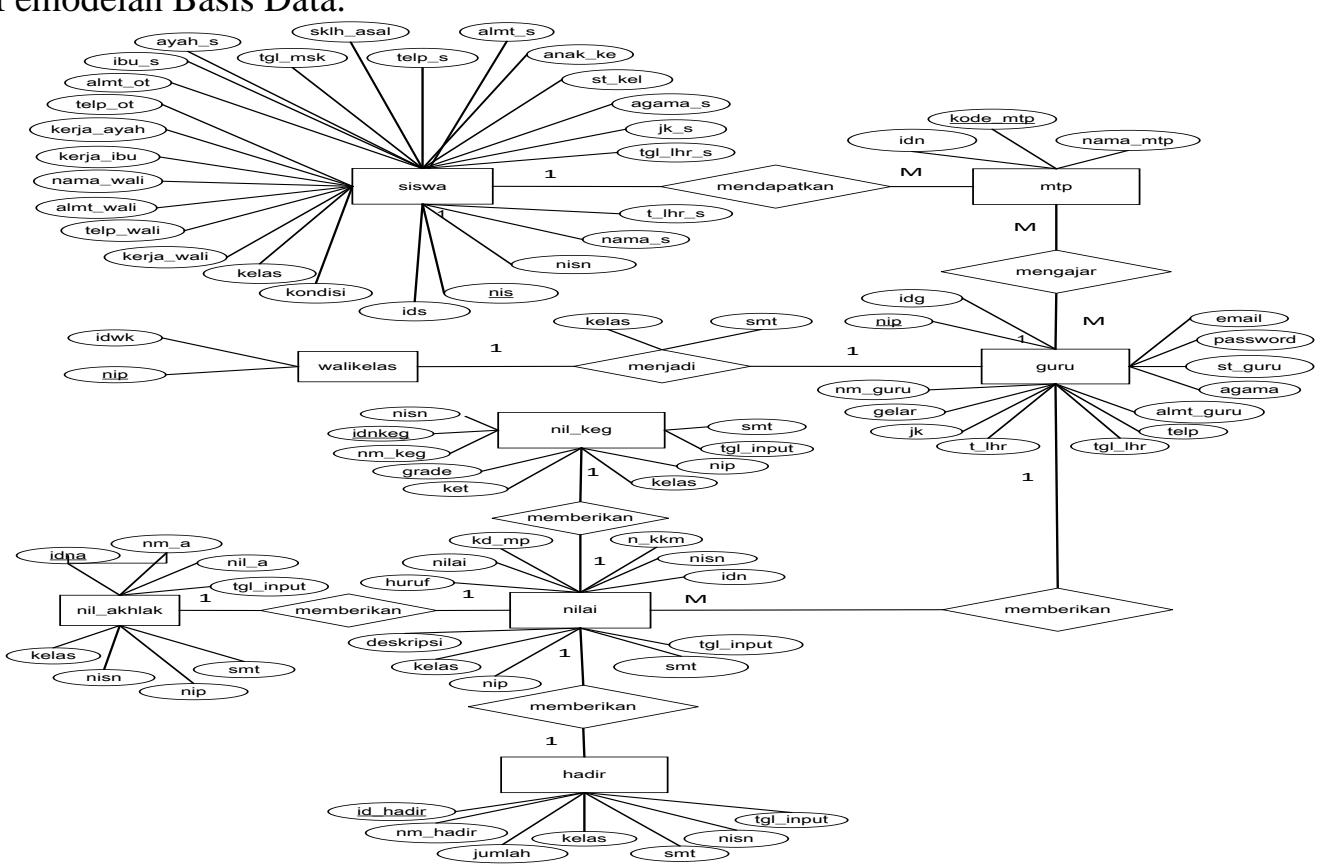

Figure 5. Database Modeling

Figure 5. The above describes the data model used for storing data contained in the digital report card information system, the tables used are 8 tables, namely students, subjects, teachers, homeroom teachers, grades, grades, moral values and attendance. 


\subsection{Coding}

a. Login page view

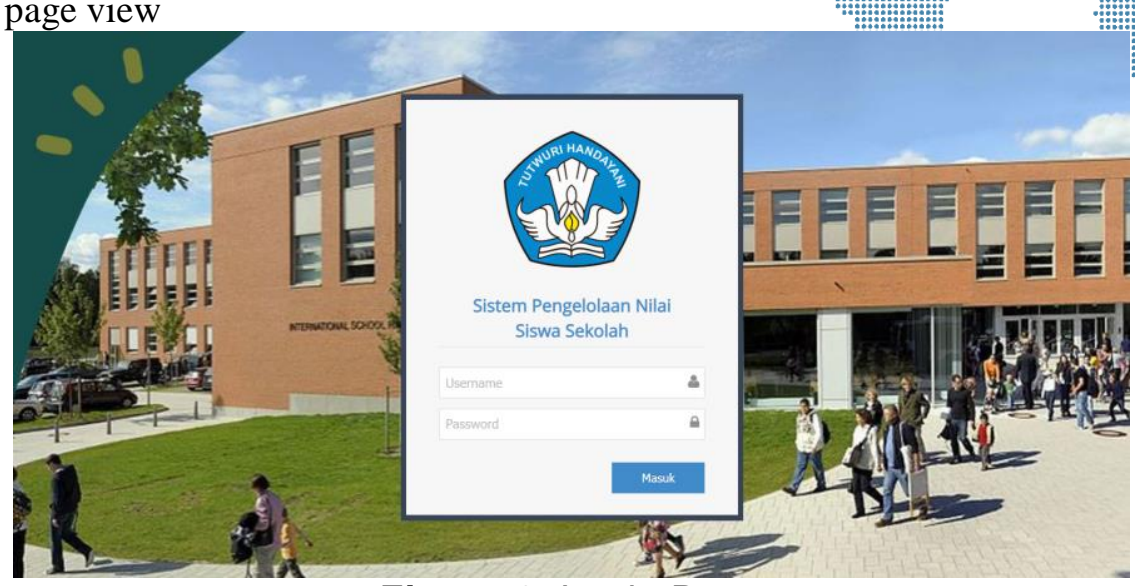

Figure 6. Login Page

b. Dashboard page view

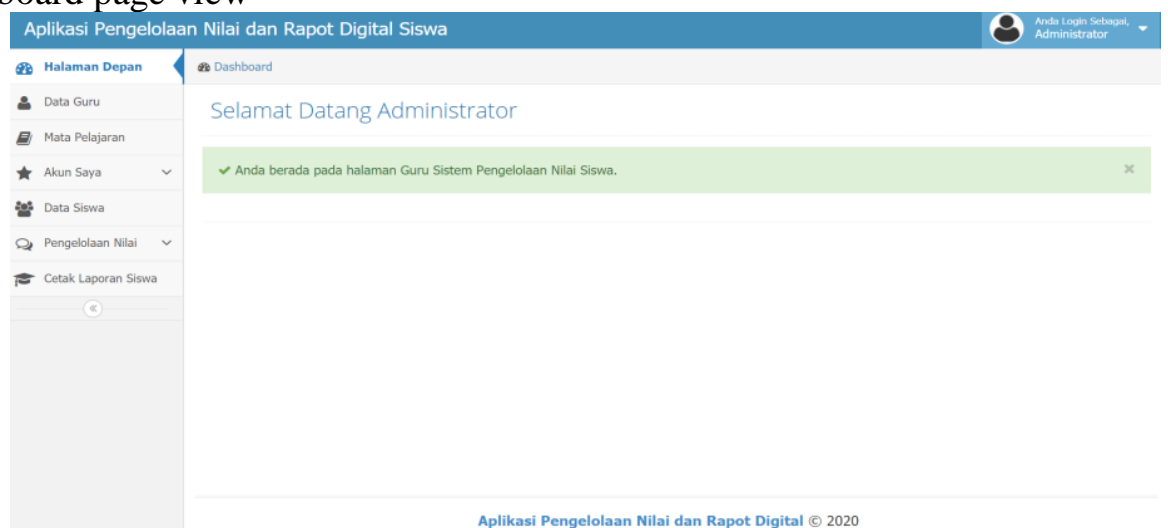

Figure 7. Dashboard Page

c. Value Management Page View.

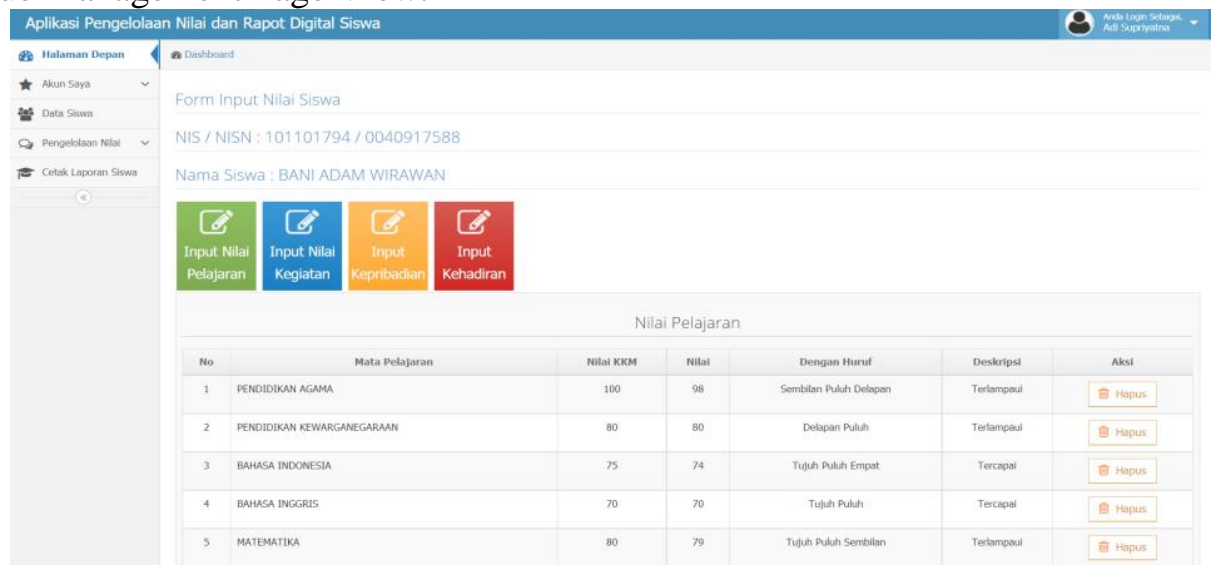

Figure 8. Value Management Page 
Nama Sekolah $\quad$ SMP XYZ

Alamat Sekola Ji. Raya Jatiwaringin No.101

\begin{tabular}{|c|c|c|c|c|c|c|}
\hline No. & \multicolumn{2}{|c|}{ Mata Pelajaran } & кКмг) & Nilai Angka & Nilai Huruf & Deskripsi \\
\hline 1 & \multicolumn{2}{|c|}{ PENDIDIKAN AGAMA } & 100 & 98 & Senbilan Plath Deliapan & Terlampaui \\
\hline 2 & \multicolumn{2}{|c|}{ PENDIDIKAN KEWARGANEGARAAN } & 80 & 80 & Delapan Puluh & Tertampaui \\
\hline 3 & \multicolumn{2}{|c|}{ BAHASA INDONESIA } & 75 & 74 & Tuluih Puluh Empat & Tercapai \\
\hline 4 & \multicolumn{2}{|l|}{ BAHASA INGGRIS } & 70 & 70 & Tyluth Puluth & Tercapai \\
\hline 5 & \multicolumn{2}{|l|}{ MATEMATIKA } & 80 & 79 & Tujuh Preuth Sembilan & Tertampaui \\
\hline 6 & \multicolumn{2}{|c|}{ ILMU PENGETAHUAN ALAM } & $\infty$ & 89 & Delispan Puluh Sembitan & Teliampaui \\
\hline 7 & \multicolumn{2}{|c|}{ ILMU PENGETAHUAN SOSIAL } & 89 & 89 & Delispan Puluh Sembitan & Teriampaui \\
\hline 8 & \multicolumn{2}{|c|}{ SENI BUDAYA } & 95 & 94 & Sembian Puluh Empat & Tetampaui \\
\hline 9 & \multicolumn{2}{|c|}{ PENDIDIKAN JASMANI, OLAHRAGA D } & 80 & 80 & Delapan Puluth & Telampaui \\
\hline 10 & \multicolumn{2}{|l|}{ KETERAMPILAN } & 85 & 85 & Delapan Pulun Lima & Tetampaui \\
\hline 11 & \multicolumn{2}{|c|}{ TEKNOLOGI INFORMASI DAN KOMUNI } & 90 & 90 & Semblan Pulan & Teriampaui \\
\hline 12 & \multicolumn{2}{|c|}{ BAHASA DAN SASTRA SUNDA } & 70 & 74 & Tuyit Puluh Empat & Tercapai $=$ \\
\hline 13 & \multicolumn{2}{|c|}{ PENDIDIKAN UINGKUNGAN HIDUP } & 75 & 76 & Tujuh Pulthe Ensm & Teriampaul \\
\hline No. & & Pengembangan Dir & & $\mathbf{N}$ & +1 & \\
\hline 1 & PRAMUKA & E- & $\mathrm{E}$ & & 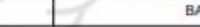 & \\
\hline & Aknt: & Kepribadian & & & Ketidakhadiran & \\
\hline AKH & & BAIK & & 1. Sakit & & Mari \\
\hline KEPF & IBADLAN & 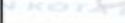 & & 2. tzin & & Hari \\
\hline & & & & 3. Tanpa & erangan & 1 Hari \\
\hline
\end{tabular}

\subsection{Testing}

The method used in testing is Black-Box Testing by testing the input and output generated by the system. The following is an example of testing carried out on a web-based digital report card information system.

Tabel 1. Pengujian Form Login

\begin{tabular}{|l|l|l|l|l|l|}
\hline No. & \multicolumn{1}{|c|}{ Testing Scenario } & \multicolumn{1}{|c|}{ Test Case } & \multicolumn{1}{|c|}{ Expected results } & \multicolumn{1}{c|}{ Test result } & Conclusion \\
\hline 1. & $\begin{array}{l}\text { User name and } \\
\text { password are not } \\
\text { filled then click the } \\
\text { login button }\end{array}$ & $\begin{array}{l}\text { User Name: } \\
\text { (empty) } \\
\text { Password: } \\
\text { (empty) }\end{array}$ & $\begin{array}{l}\text { The system will } \\
\text { deny user access } \\
\text { and return to the } \\
\text { admin login } \\
\text { menu. }\end{array}$ & $\begin{array}{l}\text { According to } \\
\text { expectations }\end{array}$ & Valid \\
\hline 2. & $\begin{array}{l}\text { Type the username } \\
\text { and password are } \\
\text { not filled then click } \\
\text { the login button }\end{array}$ & $\begin{array}{l}\text { User Name: } \\
201005238 \\
\text { Password: } \\
\text { (empty) }\end{array}$ & $\begin{array}{l}\text { The system will } \\
\text { deny user access } \\
\text { and return to the } \\
\text { admin login } \\
\text { menu. }\end{array}$ & $\begin{array}{l}\text { According to } \\
\text { expectations }\end{array}$ & Valid \\
\hline 3. & User Name is not & User Name: & The system will & According to & Valid \\
\hline
\end{tabular}




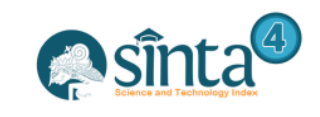

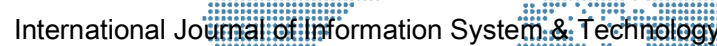

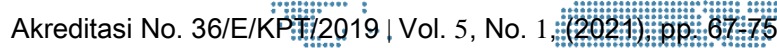

\begin{tabular}{|c|c|c|c|c|c|}
\hline No. & Testing Scenario & Test Case & Expected results & Testiresult & Condirsion \\
\hline & $\begin{array}{l}\text { filled and } \\
\text { password is filled } \\
\text { then click the login } \\
\text { button }\end{array}$ & $\begin{array}{l}\text { (empty) } \\
\text { Password: } \\
\text { P@ssw0rd }\end{array}$ & $\begin{array}{l}\text { deny user access } \\
\text { and return to the } \\
\text { admin login } \\
\text { menu. }\end{array}$ & 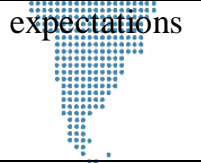 & 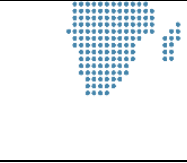 \\
\hline 4. & $\begin{array}{l}\text { Type the correct } \\
\text { Username and } \\
\text { Type incorrectly in } \\
\text { the Password and } \\
\text { then click the login } \\
\text { button }\end{array}$ & $\begin{array}{l}\text { User Name: } \\
201005238 \\
\text { (correct) } \\
\text { Password: } 123 \\
\text { (wrong) }\end{array}$ & $\begin{array}{l}\text { The system will } \\
\text { deny user access } \\
\text { and return to the } \\
\text { admin login } \\
\text { menu. }\end{array}$ & $\begin{array}{l}\text { According to } \\
\text { expectations }\end{array}$ & Valid \\
\hline 5. & $\begin{array}{l}\text { Type the User } \\
\text { Name and } \\
\text { password with the } \\
\text { correct data then } \\
\text { click the login } \\
\text { button }\end{array}$ & $\begin{array}{l}\text { User Name: } \\
201005238 \\
\text { (correct) } \\
\text { Password: } \\
\text { P@ssw0rd } \\
\text { (correct) }\end{array}$ & $\begin{array}{l}\text { The system will } \\
\text { deny user access } \\
\text { and return to the } \\
\text { admin login } \\
\text { menu. }\end{array}$ & $\begin{array}{l}\text { According to } \\
\text { expectations }\end{array}$ & Valid \\
\hline
\end{tabular}

\section{Conclusion}

Based on the results of research and design that have been carried out in the development of this information system, it can be concluded that this system can provide several advantages compared to the current system, namely efficient and effective in processing information and managing value data up to printing student report cards. In addition, this system can help make it easier for teachers and principals in the process of obtaining information and managing data and controlling student assessments in each semester.

In further research in the development of a web-based digital report card information system, namely adding the student guardian login feature as an online academic information system service. In addition, this information system can be developed into a mobile-based information system.

\section{References}

[1] Fatkhurohman A, 2019 Penerapan Teknologi Komputer Dengan Membuat Sistem Informasi Raport Digital Pada Tk Annur 3 Maguwoharjo Pros. Semin. Has. Pengabdi. Masy. 2019 November p. 421-426.

[2] Immasari I R Mansyur R A and Haroen R, 2021 PENGOLAHAN DATA NILAI SISWA SMP ABC MENGGUNAKAN PHP dan MySQL J. Inf. Syst. Applied, Manag. Account. Res. 5, 1 p. 236-248.

[3] Pangastuti A D and Priantinah D, 2019 Penerapan Sistem Informasi Raport Online Ekuitas J. Pendidik. Ekon. 7, 1 p. 1.

[4] Haris N Imtihan K and Ashari M, 2018 Perancangan Sistem Informasi Pengolahan Data Nilai Siswa Berbasis Web Di Smkn 1 Praya J. Manaj. Inform. dan Sist. Inf. 1, 2 p. 55.

[5] Dalistika N and Suherman Y, 2021 Sistem Informasi Penjadwalan Mengajar Dan Pengolahan Nilai Raport Siswa Pada Smp Negeri 2 Majalaya Karawang Berbasis Web J. Interkom J. Publ. Ilm. Bid. Teknol. Inf. dan Komun. 13, 4 p. 38-46.

[6] Christian Y, 2021 Perancangan dan Implementasi Sistem Informasi Raport K13 Berbasis Website ( Studi Kasus : Sekolah Kallista Batam ) Keywords : 1, 1 p. 750 758.

[7] Hartiningrum T M Hendrawan A T and Nugrahanti F, 2018 Rancang Bangun Sistem Informasi Data Nilai di SDN 07 Saradan Berbasis Website Pros. Semin. Nas. Teknol. Inf. dan Komun. p. 366-373.

[8] Haerani R and Robiyanto, 2019 Analisa Sistem Informasi Pengolahan Data Nilai Siswa Berbasis Web J. Sist. Inf. 6, 2 p. 103-109. 
[9] Supriyatna A, 2018 Metode Extreme Programming 9ada Pembangunan Web Aplikasi Seleksi Peserta Pelatihan Kerja J. Tek. Inform. 1 I I I P: 1-18.

[10] Ariyanti L, 2020 Sistem Informasi Akademik Dan Adminustrasi Dengan Extreme Programming Pada Lembaga Kursus Dan Pelatilitan J. Teknol. dan Sist. Inf. 1, 1 p. 90-96. 